\title{
INOVASI PENGRAJIN RACIKAN BIJI KOPI "REMPAH” HEALTHY HERBAL DAN BERDAYA SAING TINGGI BERBASIS SANTRIPRENEUR
}

\author{
Soehardjoepri ${ }^{1)}$, Muslichah Erma Widiana ${ }^{2)}$, Suhud Wahyudi ${ }^{3)}$, Wawan Hafid Syaifudin ${ }^{4)}$, \\ Mahmudah Enny Widyaningrum ${ }^{5)}$, Moch. Shofwan') \\ 1) 3) 4)Institut Teknologi Sepuluh Nopember Surabaya, ${ }^{2}{ }^{5)}$ Universitas Bhayangkara Surabaya, \\ ${ }^{6)}$ Universitas PGRI Adi Buana Surabaya \\ Email : joepri_its@yahoo.com¹),widiandra08@yahoo.co.id ${ }^{2)}$, suhud-60@yahoo.com³), \\ wawan.hafid@gmail.com ${ }^{4)}$,enny_baxx@yahoo.com ${ }^{5)}$,shofwan.moch@unipasby.ac.id ${ }^{6}$
}

\begin{abstract}
Abstrak
Kopi adalah minuman hasil seduhan biji kopi yang telah disangrai dan dihaluskan menjadi bubuk. Merupakan salah satu komoditas di dunia yang dibudidayakan lebih dari 50 negara. Dua varietas pohon kopi yang dikenal secara umum yaitu Kopi Robusta (Coffea canephora) dan Kopi Arabika (Coffea arabica). Salah satu binaan Pesantren Bisnis Indonesia (PBI) yang merintis bisnis melalui pengolahan biji kopi dan membuat kafe kopi "Antara Kita Coffee Everything" keistimewaannya owner adalah alumni Institut Teknologi Sepuluh Nopember dari beberapa angkatan dan pondok pesantren. Karena masih skala kecil untuk permodalan masih menggunakan modal pribadi, Untuk pengenalan produk melalui pameran baik yang dilaksanakan oleh pemerintah maupun asosiasi. Hasil dari kegiatan ini yaitu dilaksanakannya serah terima mesin grinder kepada mitra, dengan tujuan meningkatnya omset serta menambah gerai, karyawan, dan jejaring.
\end{abstract}

Kata Kunci : Produk, Kopi, Mesin Grinder.

\begin{abstract}
Coffee is a drink made from coffee beans that have been roasted and ground into a powder. It is one of the commodities in the world which is cultivated by more than 50 countries. Two common varieties of coffee trees are Robusta Coffee (Coffea canephora) and Arabica Coffee (Coffea arabica). One of the members of the Pesantren Bisnis Indonesia (PBI) who pioneered a business through processing coffee beans and creating a coffee cafe "Antara Kita Coffee Everything". The owner's specialty is an alumni of Institut Teknologi Sepuluh Nopember from several generations and Islamic boarding schools. Because it is still a small scale for capital, it still uses private capital, for product introduction through exhibitions, both organized by the government and associations. The result of this activity was the handover of the grinder machine to partners, with the aim of increasing turnover and increasing outlets, employees, and networks.
\end{abstract}

Keywords : Products, Coffee, Grinder Machines.

\section{PENDAHULUAN}

Menurut Undang-Undang Nomor 9 Tahun 1995 tentang Usaha Kecil Pasal 1 ayat 1 bahwa industri kecil adalah kegiatan ekonomi rakyat yang berskala kecil dan memenuhi kriteria kekayaan bersih atau hasil penjualan tahunan lebih besar daripada kekayaan bersih dan hasil penjualan tahunan serta kepemilikan sebagaimana diatur dalam UndangUndang. Pengembangan industri pada saat ini tidak hanya bergantung pada industri skala besar saja, melainkan juga mulai diperhatikan peranan industri kecil. Industri kecil merupakan pilar utama dalam pengembangan ekonomi daerah. Pada sisi keberadaan industri kecil menjadi sektor usaha yang menjadi tumpuan tenaga kerja 
di Indonesia. Pengembangan dari industri kecil dan rumah tangga menjadi lebih efektif karena selain memperluas lapangan pekerjaan dan kesempatan usaha juga dapat mendorong pembangunan daerah dan pedesaan di Indonesia. Menurut Schumpeter yang dimaksud dengan pembangunan ekonomi merupakan adanya suatu perubahan yang dilakukan secara spontan dan dilaksanakan dengan tidak terputus-putus. Pembangunan ekonomi utamanya disebabkan karena adanya suatu perubahan terutama perubahan yang terjadi dalam suatu lapangan industri maupun perdagangan (Suryana, 2000). Karim (2011) berpendapat bahwa produksi adalah sebuah proses yang telah terlahir dimuka bumi ini semenjak manusia menghuni planet ini. Produksi lahir dan tumbuh dari menyatunya manusia dengan alam. Berdasarkan poin tersebut maka produksi adalah kegiatan menghasilkan atau menambah nilai kegunaan suatu barang atau jasa untuk memenuhi kebutuhan manusia. Secara teknis, produksi adalah proses mentransformasi input menjadi output (Yuniarti, 2016).

Ada dua spesies dari tanaman kopi yaitu Arabika dan Robusta. Arabika merupakan kopi tradisional, dan dianggap paling enak rasanya, sedangkan Robusta memiliki kafein yang lebiih tinggi (Anonim, 2008). Kopi adalah minuman hasil seduhan biji kopi yang telah disangrai dan dihaluskan menjadi bubuk. Merupakan salah satu komoditas di dunia yang dibudidayakan lebih dari 50 negara. Dua varietas pohon kopi yang dikenal secara umum yaitu Kopi Robusta (Coffea canephora) dan Kopi Arabika (Coffea arabica). Kopi robusta dapat dikatakan sebagai kopi kelas 2, karena rasanya yang lebih pahit, sedikit asam dan mengandung kafein dalam kadar yang jauh lebih banyak. Terkait dengan pengolahan biji kopi menjadi kopi bubuk di Pakis-Sawahan-Surabaya ada salah satu UKM yang menjalankan kegiatan usaha produksi kopi dengan cita rasa dan berdaya saing tinggi yaitu: yaitu binan dari UD. Al Falah dengan pemilik/pimpinannya RR. Henny Eka Ferdian HP yang selama ini melakukan binaan ataupun coching terhadap binaannya antara lain Pesantren Bisnis Indonesia (PBI) yang bekerja secara sosial. Menurut bu Henny produksi kopi terinspirasi dari banyaknya warung kopi dan ingin memberikan nuansa baru di dunia perkopian, karena kopi yang disajikan adalah kopi kesehatan yang mengandung rempah-rempah dimana hal itu karena pengalaman pribadi merawat orang tua yang sakit diabet, kolesterol, darah tinggi, jantung, ginjal dan kanker Alhamdulillah dengan kopi herbal penyakit tidak bertambah parah dan bisa stagnan sampai orang tua tersebut wafat di usia lanjut. Salah satu binaan PBI yang merintis bisnis melalui pengolahan biji kopi dan membuat kafe kopi "Antara Kita Coffee Everything" keistimewaannya owner adalah alumni ITS dari beberapa angkatan dan pondok pesantren. Karena masih skala kecil untuk permodalan masih menggunakan modal pribadi, Untuk pengenalan produk melalui pameran baik yang dilaksanakan oleh pemerintah maupun asosiasi.

Berawal dari pertemanan, belajar bersama dan memiliki hobi yang sama yaitu minum kopi menjadikan gagasan kelompok pelajar ini setelah lulus kuliah di ITS untuk membuka usaha kopi cafe yang diberi nama "Antara Kita Coffee \& Everything", yaitu dari alumni ITS dengan berbagai fakultas antara lain: Fakultas Teknik Kelautan, Fakultas Teknologi Industri, Fakultas Teknik Sipil dan Perencanaan. Biji kopi mentah berasal dari beberapa kota seperti Temanggung Jawa Tengah dan Malang Jawa Timur, Lampung Sumatera, Medan dan Situbondo dengan proses digoreng hingga ditumbuk menjadi kopi bubuk. Kopi "Antara Kita Coffee \& Everything" tersebut memunculkan rasa berbeda dibanding kopi pada umumnya. Kopi dari "Antara Kita Coffee \& Everything" itu berasa lembut, setelah penikmat kopi nyeruput, mereka baru merasakan rasanya. Rasanya tidak nyentak (terasa keras di tenggorokan), tapi lembut dan aromanya khas. Untuk proses produksi sangrai hingga pemasaran bersama-sama dikerjakan oleh kelompok para alumni dengan sesuai job discnya masing-masing. Kopi dari café "Antara Kita Coffee \& 
Everything" ini memiliki khasiat meningkatkan stamina dan rasanya beda, lebih segar dan harum. Dengan harga penjualan per gelas bervariasi mulai Rp. 5.000 s.d Rp. 25.000,-. Disini konsumen dapat menyeduh sendiri sambil belajar teknik penyeduhan kopi sehingga mendapatkan rasa yang diinginkan.

Kemampuan pembuatan kopi bubuk diperoleh saat mengikuti pembinaan Pesantren Bisnis Indonesia dengan Pembinanya Ibu Henny dengan merk kopinya "Bundoranto", menjamurnya warung kopi dan ingin memberikan nuansa baru di dunia perkopian yaitu kopi yang disajikan adalah kopi kesehatan yang mengandung rempah-rempah yang telah terbukti khasiatnya yaitu dari orang tua Pembina yang memiliki berbagai penyakit: diabet, kolesterol, darahtinggi, jantung, ginjal dan kanker Alhamdulillah dengan kopi herbal penyakit tidak bertambah parah dan dapat stak tetap pada posisi sakit sampai beliau wafat diusia yang sudah sepuh.

Dapatlah disampaikan tahapan pembuatan dari kopi ini sebagai berikut:

a. Kopi yang digunakan adalah bahan kopi robusta dan yang terpilih untuk dicampur dengan rempah sehingga menghasilkan cita rasa yang pas yaitu kopi robusta Dampit;

b. Setelah dirosting kopi dibuat bubuk dan bahan rempah seperti cengkeh, kapulaga, jahe, kayu manis, jinten dan purwaceng;

c. Purwaceng adalah bahan tambahan dari rempah lokal yang dalam prosesnya dikeringkan dulu lalu dihaluskan dan dicampur jadi satu.

Beberapa permasalahan yang menjadi pemicu bisnis ini yaitu diantaranya a) pada produksi kopi "BundoRanto" selama ini dalam proses sangrai menggunakan alat-alat scala rumah tangga

\section{HASIL DAN PEMBAHASAN}

Kegiatan pengabdian ini dihadiri oleh pemilik usaha, pemuda, dan masyarakat. Kegiatan ini diawali dengan pemberian alat TTG, pembagian handout, sosialisasi, tanya jawab. Hasil dari kegiatan ini dan sehingga tidak dapat produktif dan kapasitas kurang. Sehingga sangat tidak efektif dan efisien dan mengurangi aroma kopi sebagai cita rasa dari sebuah bubuk kopi, b) manajemen SDM mengalami kesulitan mencari tenaga kerja yang mempunyai komitmen, tanggung jawab dalam bekerja, c) wilayah pemasaran produk kopi bubuk "BundoRanto" belum luas.

\section{METODE PELAKSANAAN}

Sosialisasi dan penyerahan alat terkait inovasi pengrajin racikan biji kopi "rempah" healthy herbal dan berdaya saing tingi berbasis santripreneur dilaksanakan dengan mitra UKM Alumni ITS Keputih Tegal Timur Surabaya dilakukan pada tanggal 15 Juli 2020. Sasaran kegiatan adalah mitra alumni ITS usaha kafe "Antara Kita Coffee \& Everything" Jalan Keputih Tegal Timur No. 21 Surabaya dan warga sekitar. Harapannya setelah pelaksanaan kegiatan ini meningkatnya omset penjualan kopi serta meningkatkanya pengetahuan mitra dan masyarakat dalam usaha kopi. Tahapan kegiatan pengabdian kepada masyarakat meliputi: mengidentifikasi permasalahan yang dihadapi oleh mitra dan masyarakat;
a. Survei lapangan untuk
b. Pendekatan kualitatif deskriptif untuk mengidentifikasi kondisi eksisting mitra dan masyarakat;
c. Mendesain kegiatan sesuai hasil analisis;
d. Menentukan sasaran kegiatan;
e. Pelaksanaan kegiatan berupa sosialisasi;
f. Evaluasi hasil pengabdian kepada masyarakat;
g. Pelaporan dan penyusunan artikel ilmiah.

permasalahan yang dihadapi dapat dilihat pada penjelasan berikut :

\section{a. Beberapa Permasalahan Yang Dihadapi Kopi Dari "Bundoranto" Café Adalah :}

Akses pasar yang sangat terbatas. Ketersedian akses pasar adalah unsur penting dalam perencanaan peningkatan 
kapasitas produk. Oleh sebab itu, akses pasar yang terbatas saat ini perlu diluaskan sehingga produk kopi bubuk yang dihasilkan memiliki jaringan pemasaran yang kuat sehingga industri mitra dengan mudah dapat mengembangkan diri baik untuk pengembangan jenis produksi ataupun jaringan pemasaran.

Upaya untuk mewujudkan UKM yang meningkat secara ekonomi dan usaha yang berkelanjutan melalui introduksi teknologi proses pengolahan kopi bubuk dan manajemen usaha terus dilakukan. Hal ini akan lebih efektif apabila didukung oleh satu wadah yang bersifat menjadi penghubung antara lembaga perguruan tinggi dan industri mitra. Bahkan media yang bersifat membina ini dapat menjadi agent of transfert technology bagi UKM lain, sehingga tidak hanya satu UKM yang dibina menjadi usaha yang maju dan mandiri serta berkualitas.

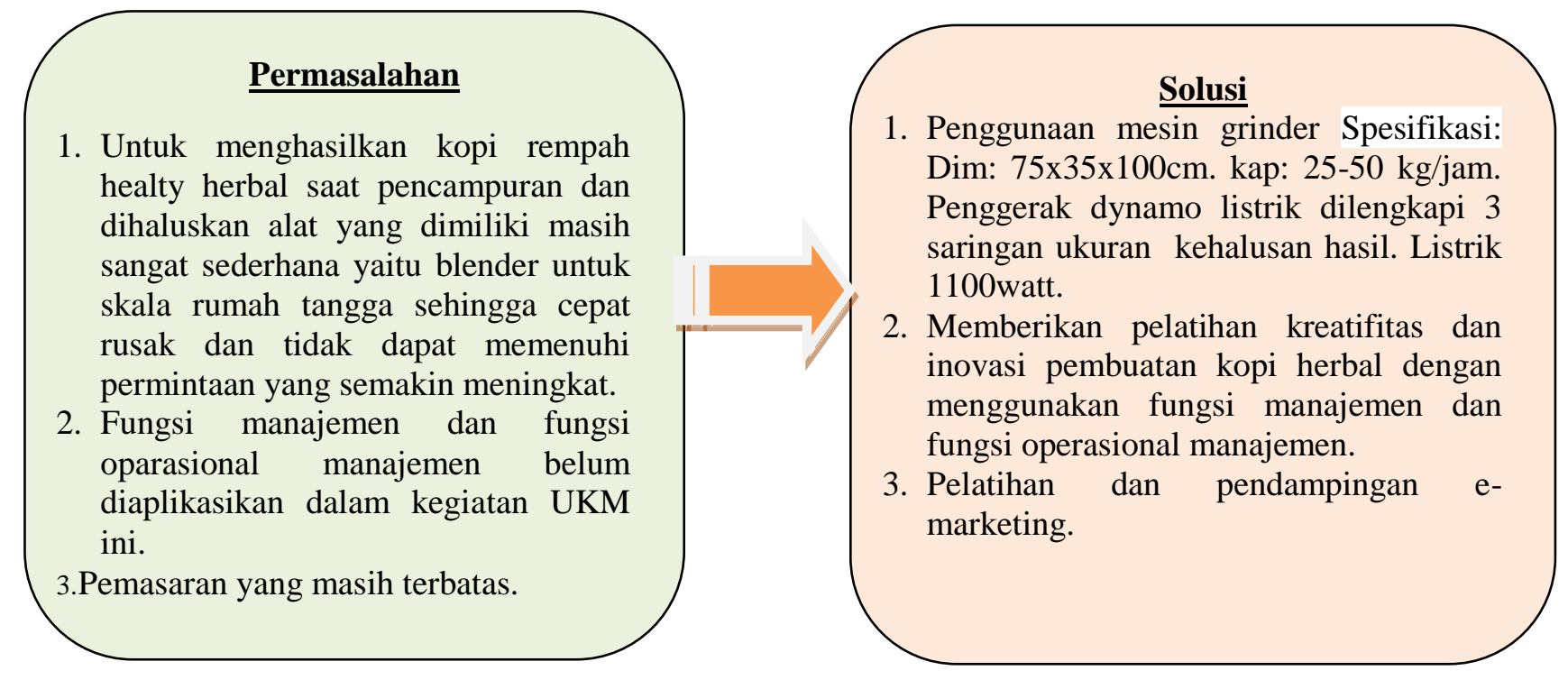

\section{Gambar 1. Tahapan Permasalahan dan Solusi}

Hasil dari identifikasi yaitu untuk kelancaran dan aktivitas bekerja yg terkondisi nyaman maka proses produksi kopi "BundoRanto" jam kerja diawali pada pukul 06.30 dan berakhir pada pukul 16.15 Wib. Dengan sistem kehadiran secara pencatatan manual. Dengan tenaga kerja sebanyak 3 orang yang tetap, bila pemesanan banyak baru ditambah bagian produksi pembuatan kopi dari warga sekitar.

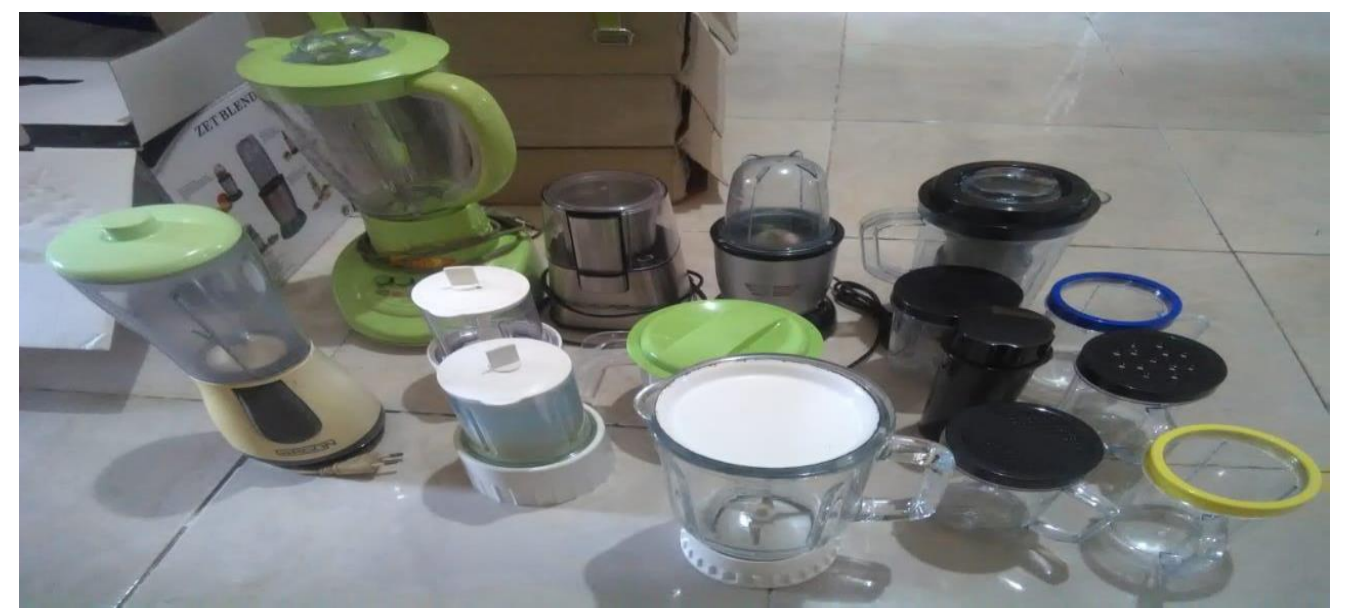

Gambar 2. Peralatan Produksi Selama Ini Yang Digunakan Tidak Efektif Dan Efisien 

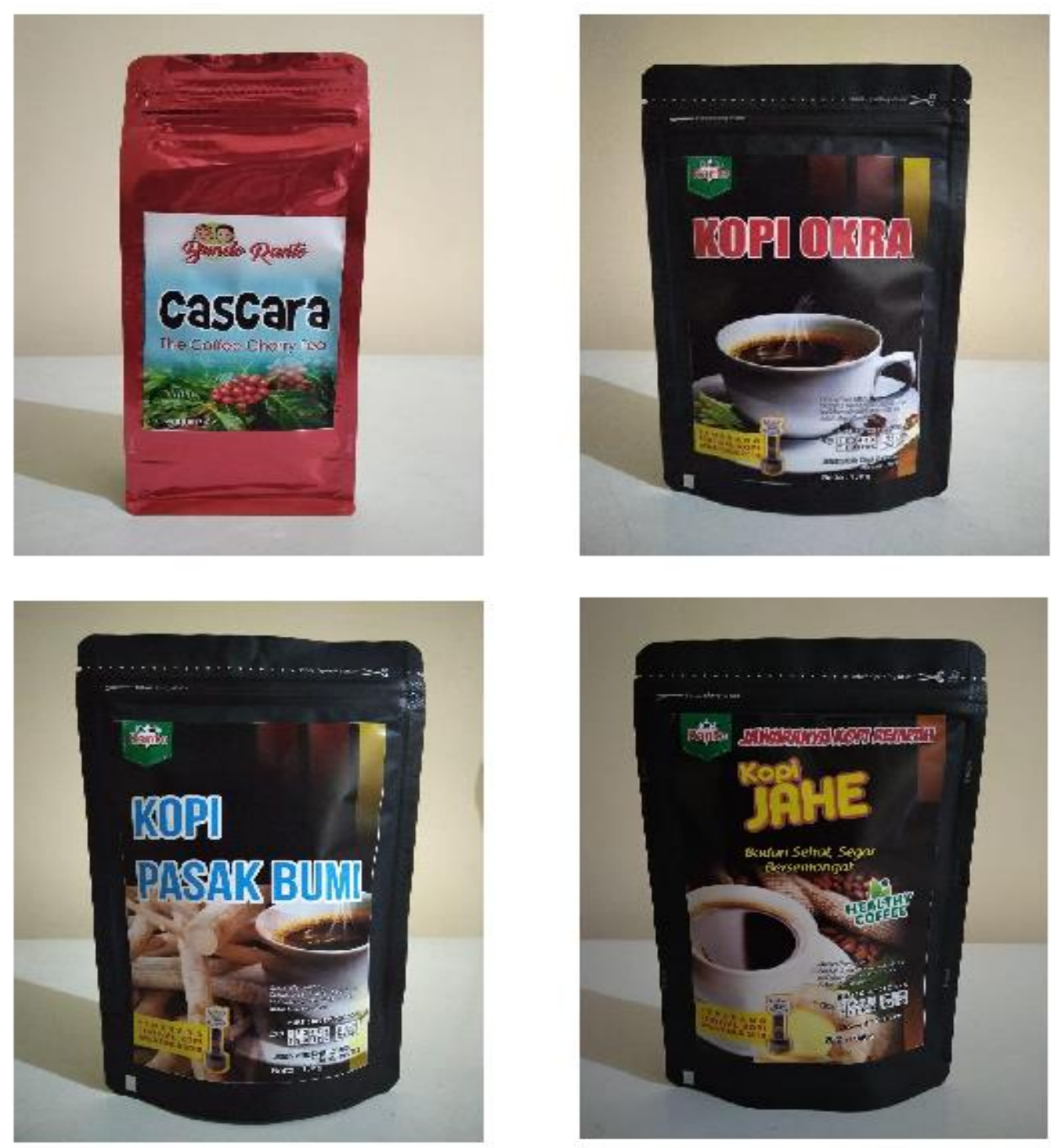

Gambar 3. Kopi "BundoRanto" 


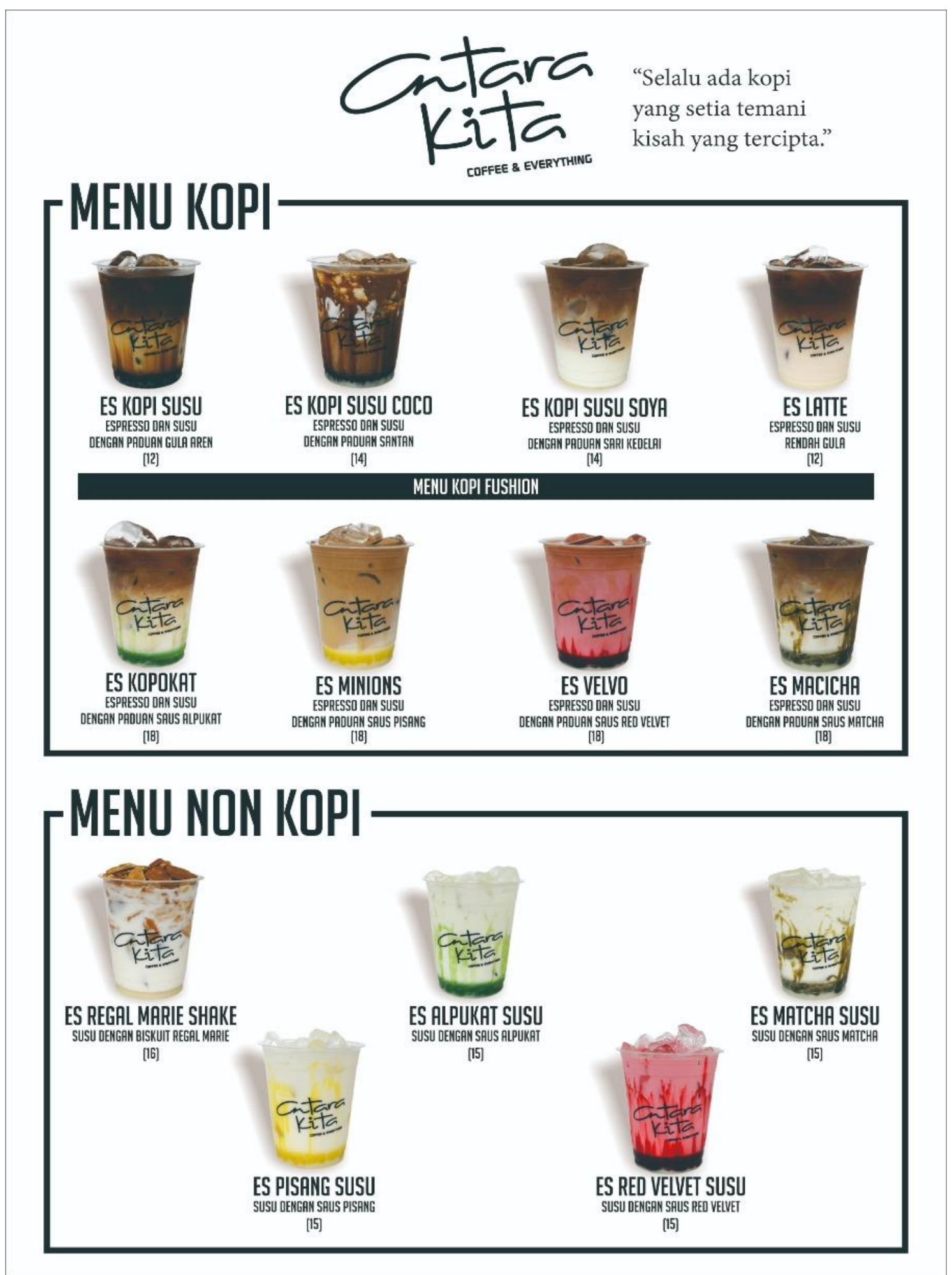

Gambar 4. Kopi "BundoRanto" yang diproses Menjadi Minuman Kopi di Café "Antara Kita" Alumni ITS 

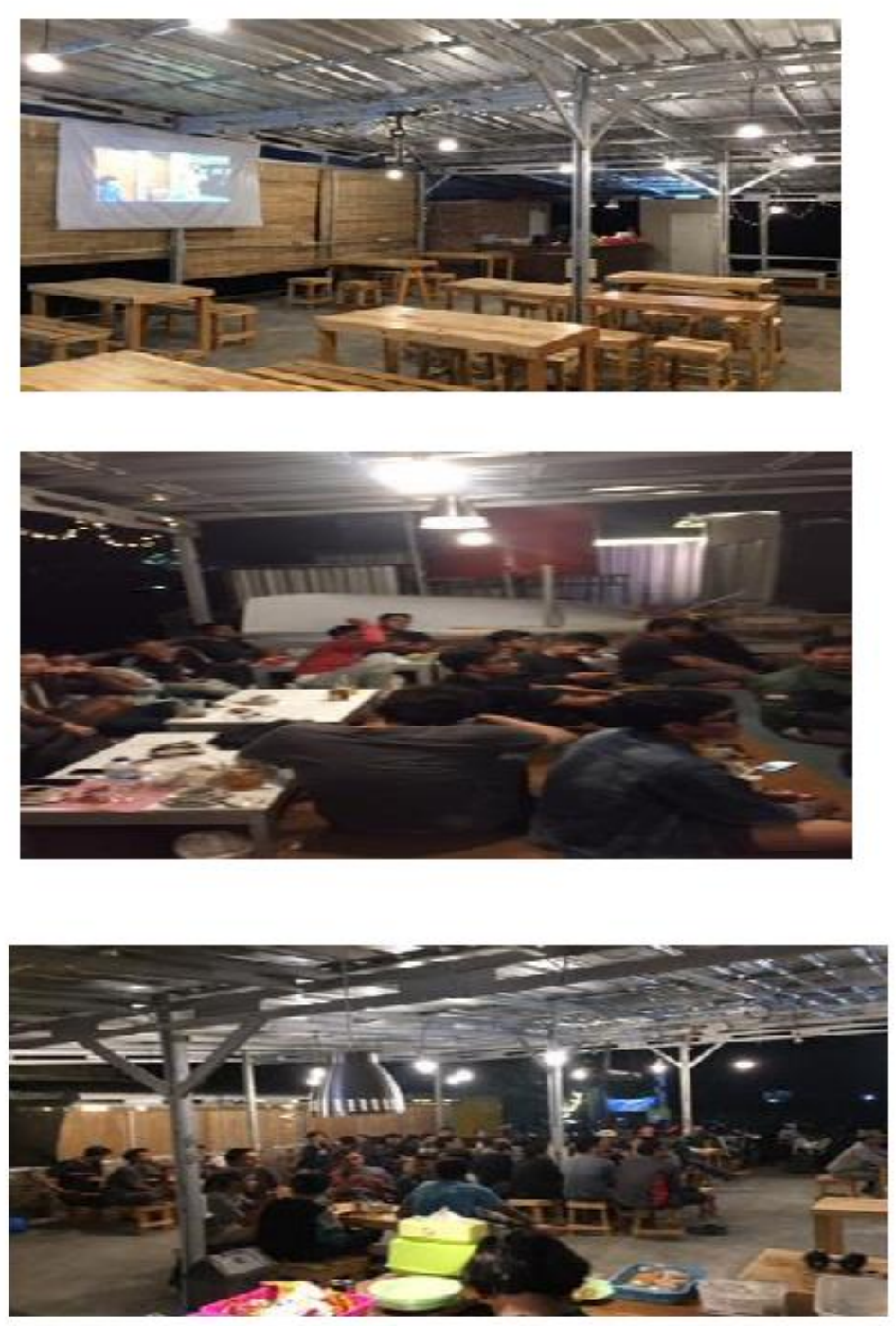

Gambar 5. Suasana "Café Kita" Milik Alumni ITS

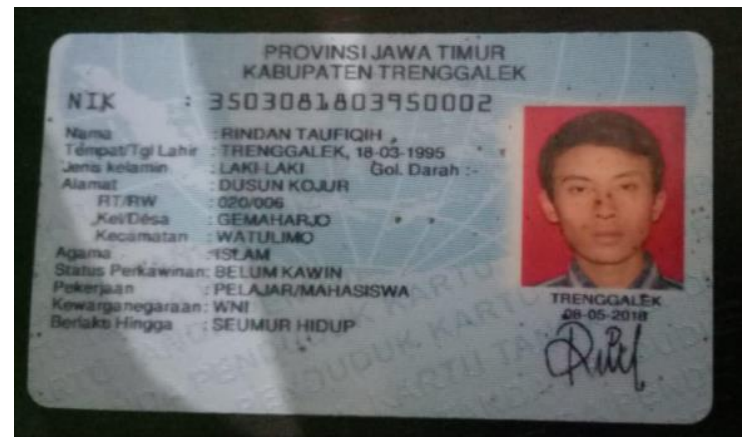

Gambar 6. KTP Mitra 1 


\section{b. Luaran Dan Target Capaian}

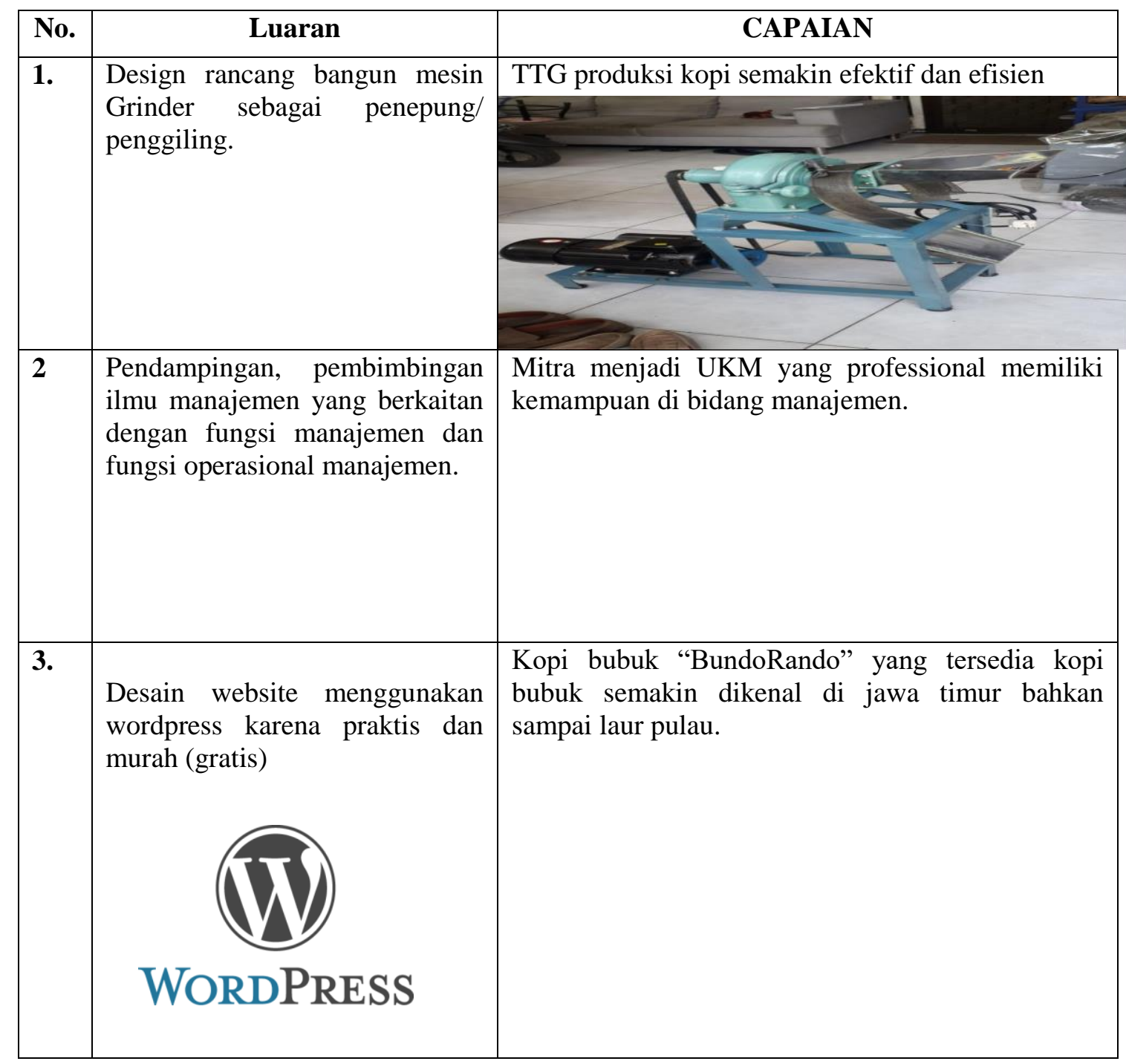
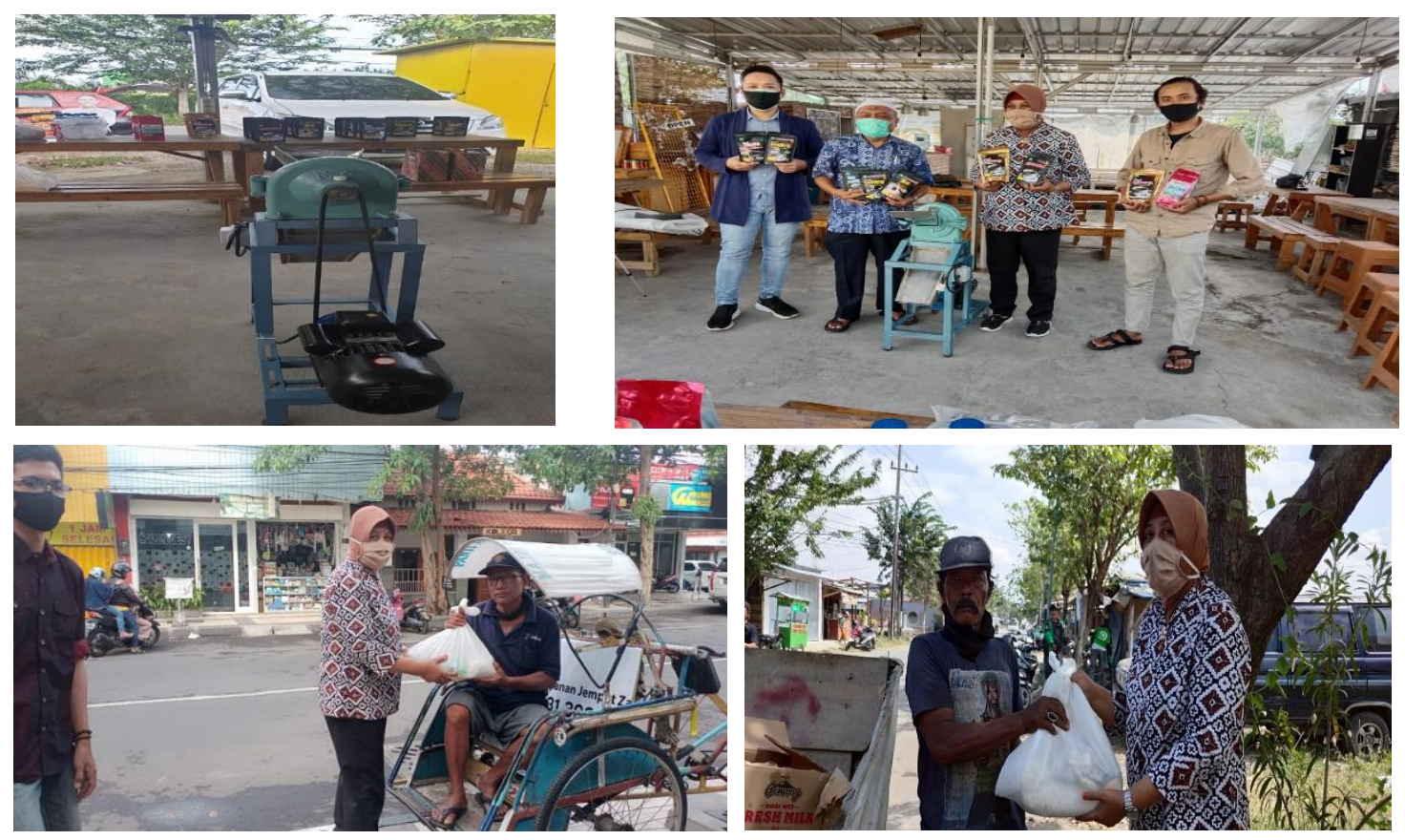

Gambar 7. Penyerahan TTG Mesin Grinder dan Proses Penyerahan Produk TTG dan Bakti Sosial

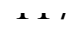


Hasil terahir setelah proses desain dan pembuatan alat selesai, maka kegiatan selanjutya dari kegiatan pengabdian ini yaitu penyerahan TTG Mesin Grinder kepada mitra sehingga dalam proses

\section{KESIMPULAN}

Kegiatan sosialisasi dan penyerahan alat terkait inovasi pengrajin racikan biji kopi "rempah" healthy herbal dan berdaya saing tingi berbasis santripreneur dilaksanakan dengan mitra UKM Alumni ITS Keputih Tegal Timur Surabaya dilakukan pada tanggal 15 Juli 2020. Sasaran kegiatan adalah mitra alumni ITS usaha kafe "Antara Kita Coffee \& Everything" Jalan Keputih Tegal Timur No. 21 Surabaya dan warga sekitar. Mitra dan Masyarakat sangat antusias dalam kegiatan ini. Diharapkan pasca kegiatan ini semakin meningkat omsetnya dan menambah tenaga kerja dan jejaring. pengolahan kopi lebih maksimal hasil yang didapatkan. Kemudian tim juga melakukan bakti sosial berupa pemberian sembako kepada masyarakat yang membutuhkan dan bersyukur diterima dengan baik.

\section{REFERENSI}

Suryana. (2000). Ekonomi Pembangunan: Problematika dan Pendekatan. Jakarta: Salemba Empat.

Undang-Undang Nomor 9 Tahun 1995 tentang Usaha Kecil

Karim, Adiwarman A. (2011). Ekonomi Makro Islami. Jakarta: PT. Raja Grafindo Persada.

Anonim, (2008). Iso farmakoterapi. Jakarta: PT.ISFI Penerbitan.

Yuniarti, Vina Sri. (2016). Ekonomi Mikro Syariah. Bandung: CV. Pustaka Setia. 